\title{
Beberapa Faktor yang Mempengaruhi Pemberian Makanan Pendamping Air Susu Ibu (MP ASI) Dini pada Bayi Usia 0-6 Bulan
}

\author{
Yovi Yuliani \\ Akademi Kebidanan Bogor Husada \\ Jalan Sholeh Iskandar No.4 Jalan Baru. Kedung Badak, Tanah Sereal - Kota Bogor \\ E-mail : yovibhp@gmail.com
}

\begin{abstract}
Abstrak
Pemberian MP-ASI bayi 0 - 6 bulan dianggap terlalu dini, sebab zat gizi dalam ASI sudah memenuhi kebutuhan bayi selama 6 bulan umur bayi. Penelitian bertujan untuk mengetahui faktor yang mempengaruhi pemberian MP ASI Dini pada Bayi. Bersifat deskriptif analitik dengan pendekatan cross sectional, tehnik pengumpulan data primer untuk mengetahui pengetahuan ibu dan data sekunder yang berasal buku register ibu yang memiliki bayi 0-6 bulan, populasi seluruh ibu yang mempunyai bayi usia 0-6 bulan sebanyak 361 orang. Tehnik pengambilan sampel incidential sampling yaitu setiap ibu yang datang diberikan kuesioner, yaitu penelitian sebanyak 95 orang. Hasil penelitian menunjukan sebagian besar bayi usia 0-6 bulan tidak diberikan MP-ASI Dini sebanyak $76(80 \%)$ yang diberikan MP-ASI Dini sebanyak 19 (20\%), distribusi frekuensi berdasarkan rentan usia <20$>35$ tahun sebanyak 49 responden $(51 \%)$, paritas multipara sebanyak 81 responden (85\%), berpendidikan rendah sebanyak 59 responden $(62 \%)$, tidak bekerja sebanyak 44 responden $(47 \%)$, pengetahuan kurang sebanyak 65 responden (70\%). Kesimpulan terdapat faktor yang mempengaruhi dengan adanya hubungan antara pemberian MP-ASI Dini dengan pendidikan, paritas, pekerjaan dan pengetahuan ibu. Saran untuk lebih ditingkatkan pengetahuan informasi penting nya manfaat ASI Ekslusif dan pemberian MP ASI yang tepat untuk bayi usia 6 bulan.
\end{abstract}

Kata Kunci : MP ASI Dini, Usia, Paritas, Pekerjaan, Pendidikan, Pengetahuan

\begin{abstract}
Giving MP-ASI infants 0-6 months is considered too early, because the nutrients in breast milk have met the needs of babies for 6 months of age. The research was conducted to determine the factors that influence the provision of MP Early Breastfeeding in Infants. Descriptive analytic with cross sectional approach, the technique of collecting primary data to find out mother's knowledge and secondary data originating from the mother register that has babies 0-6 months, the population of all mothers who have babies aged 0-6 months is 361 people. The sampling technique is incidential sampling, ie every mother who comes is given a questionnaire, which is a study of 95 people. The results showed that the majority of infants aged 0-6 months were not given Early MP-ASI as many as 76 (80\%) given Early MP-ASI as many as 19 (20\%), frequency distribution based on $<20$-> 35 years old as many as 49 respondents (51\%), multipara parity as many as 81 respondents (85\%), low education as many as 59 respondents (62\%), not working as many as 44 respondents (47\%), less knowledge as much as 65 respondents (70\%). Conclusions there are factors that influence the relationship between giving MPASI Early with education, parity, work and mother's knowledge. Suggestions for more enhanced knowledge of the importance of the benefits of exclusive breastfeeding and the provision of MP breast milk are right for babies aged 6 months.
\end{abstract}

Keywords : MP ASI Early, Age, Parity, Employment, Education, Knowledge 


\section{Pendahuluan}

Air Susu Ibu (ASI) adalah makanan terbaik dan alamiyah untuk bayi. Menyusui merupakan suatu proses alamiah namun sering ibu-ibu tidak berhasil menyusi lebih dini dari yang semestinya. ${ }^{1}$ Makanan pendamping ASI (MP ASI) adalah makanan minuman penamping ASI yang diberikan pada bayi atau anak yang berumur diatas 6 bulan, bila diberikan sebelum bayi berusia 6 bulan berarti bayi tersebut tidak mendapatkan ASI secara ekslusif padahal ASI merupakan makanan yang bergizi sehingga tidak memerlukan tambahan komposisi. Disamping itu ASI mudah dicerna oleh bayi dan langsung terserap. $^{2}$

MP-ASI adalah makanan tambahan selain ASI yang diberikan pada bayi sampai usia 24 bulan, sehingga MP-ASI diberikan tepat waktu pada usia 6-12 bulan, karena pada usia tersebut merupakan waktu yang sangat rawan terjadi malnutrisi. Namun, di Indonesia masih banyak kebiasaan pemberian makan bayi yang belum sesuai dengan umurnya. Banyak ibu yang memberikan makanan terlalu dini kepada bayinya. Terdapat $32 \%$ ibu yang memberikan makanan tambahan kepada bayi yang berumur 2-3 bulan, seperti bubur, nasi, pisang dan $69 \%$ terhadap bayi yang berumur 4-5 bulan. ${ }^{3}$ Hasil penelitian yang dilakukan di Provinsi Jawa Barat menunjukkan bahwa 56, $8 \%$ ibu memberikan makanan pendamping ASI terlalu dini pada bayi 0-6 bulan dan sebesar 43, $2 \%$ ibu tidak memberikan makanan pendamping ASI terlalu dini. ${ }^{4}$

Di Indonesia hampir semua ibu memberikan ASI kepada bayinya dan itu dilakukan dalam waktu yang cukup panjang, namun praktek pemberian makanan atau minuman pralaktal juga sangat banyak dilakukan, hal ini terlihat dari beberapa hasil penelitian berikut; dalam hasil penelitian ditemukan sebanyak $46,8 \%$ bayi baru lahir yang telah diberi makanan selain ASI, adapun bentuk makanan tersebut adalah susu buatan, air gula, air teh, air tajin, nasi yang di haluskan dan pisang yang di haluskan. ${ }^{5}$ Peran petugas kesehatan adalah melakukan pelayanan dasar, pengobatan dan tindakan kesehatan lain. Dalam pemberian MP-ASI peran petugas kesehatan sangat penting karena promosi pemberian MP-ASI dilakukan petugas kesehatan yaitu dengan memberi tahu cara dan waktu yang tepat. $^{6}$

Hasil penelitian di Bogor tahun 2010 menunjukan bahwa 18,7\% dari ibu-bu di anjurkan oleh petugas kesehatan untuk memberikan susu formula pada minggu pertama setelah kelahiran. Temuan lainnya di studi tersebut adalah bahwa $14,8 \%$ dan bidan menyatakan setuju untuk memberikan susu formula kepada bayi baru lahir. ${ }^{7}$ Tetapi studi MPASI yang di lakukan di lokasi pada tahun 2011 yakni Bogor, Indramayu (Jawa Barat), Purworejo (Jawa Tengah), Jombang (Jawa Timur), dan Barru (Sulawesi Selatan) ternyata menunjukan bahwa antara 7-40\% (rata-rata 21\%) ibu telah memberika MP-ASI komersial (SUN, Nestle, Milna) setiap hari pada bayi di bawah umur 5 bulan. ${ }^{8}$ Pemberian MP-ASI pada bayi $0-6$ bulan di anggap terlalu dini, sebab zat gizi dalam ASI sudah memenuhi kebutuhan bayi selama 6 bulan umur bayi. Setelah 6 bulan bayi diberi MP-ASI karena zat gizi dalam ASI sudah tidak mencukupi untuk pertumbuhan bayi secara optimal. ${ }^{6}$ Salah satu faktor yang menentukan tingkat kesejahteraan dan kesehatan manusia adalah gizi. Gizi merupakan faktor penting yang memegang peranan dalam siklus kehidupan manusia terutama bayi dan anak yang nantinya akan menjadi generasi penerus bangsa. ${ }^{1}$ Perhatian pemerintah antara lain melalui Usaha Perbaikan Gizi Keluarga (UPGK), penimbangan dengan menggunakan KMS (kartu Menuju Sehat) sebagai alat untuk mengetahui tingkat pertumbuhan anak, upaya peningkatan penggunaan Air Susu Ibu (ASI), Kelurga Berencana dan Lain-lain. ${ }^{7}$

Pemberian ASI bagi bayi adalah cara terbaik untuk penigkatan kualitas sumber daya manusia sejak dini yang akan menjadi generasi penerus bangsa. Karena pemberian ASI berarti memberikan zat gizi tinggi terutama untuk pertumbuhan dan perkembangan syaraf dan otak. $^{7}$ Diperkirakan $80 \%$ dari jumlah ibu yang melahirkan ternyata mampu menghasilkan air susu dalam jumlah yang cukup untuk keperluan bayinya secara penuh tanpa makanan tambahan. Selama enam bulan pertama. Bahkan ibu yang gizinya kurang baik pun sering dapat menghasilkan ASI cukup tanpa makanan tambahan selama tiga bulan pertama. ${ }^{6}$

Ada beberapa hal yang menyebabkan usaha peningkatan pengguna ASI di Indonesia sampai 
saat ini belum seperti yang diharapkan antara lain adalah pengetahuan ibu dan petugas kesehatan mengenai kenunggulan ASI belum memadai, tata laksana penggunaan ASI di fasilitas kesehatan belum benar, masih banyaknya yang menggunakan susu formula tanpa alasan yang tepat, iklan susu formula yang sering menyesatkan masih bebas di tayangkan di media masa. $^{9}$

Beberapa penelitian menyebutkan, angka kejadian diare dan kematian pada bayi jauh lebih tinggi terjadi pada bayi yang mengkonsumsi susu formula atau makanan pengganti ASI lainnya terutama di negara negara miskin dan berkembang. Angka kematian bayi dan angka kejadian kurang gizi masih tinggi di Indonesia. Berbagai upaya telah dilakukan untuk menanggulanginya, antara lain dengan cara melaksanakan "Breast Feeding". ${ }^{10}$ Dengan harapan para petugas kesehatan atau mereka yang terkait memperoleh pengetahuan yang memadai, sehingga tidak ragu - ragu lagi dalam menggalakkan penggunaan ASI di masyarakat. Lebih lebih dengan gencarnya promosi susu formula, maka pengetahuan tentang ASI dan laktasi harus benar-benar di pahami. Dengan demikian kita tidak akan mudah untuk menggantikan ASI dengan susu kaleng tanpa memperhatikan indikasi yang jelas. ${ }^{11}$

Mempersiapkan ibu selama hamil untuk pemberian ASI Ekslusif. Baik nutrisi ataupun pengetahuan sangat memegang peranan penting untuk pemberian ASI Eksklusif. Pengalaman dalam penggunaan ASI selama 15 tahun menunjukkan bahwa hambatan utama penggunaan ASI ternyata adalah kurang sampainya pengetahuan yang benar tentang ASI dan menyusui pada ibu. ${ }^{2}$ Peneliti melakukan study pendahuluan terhadap ibu yang mempunyai bayi 0-6 bulan di BPM Bidan Y Kabupaten Bogor sebanyak 20 orang dengan tehnik wawancara langsung mendapatkan informasi bahwa ibu yang memberikan MP ASI DINI yaitu berupa susu formula sebanyak 12 orang, padahal menurut teori bahwa Bayi yang di beri susu selain ASI mempunyai resiko 17 kali lebih besar mengalami diare, dan 3 sampai 4 kali lebih besar kemungkinan terkena ISPA dibandingkan dengan bayi yang mendapatkan ASI. ${ }^{1}$ Bidan merupakan mata rantai yang sangat penting karena kedudukannya sebagai ujung tombak dalam upaya peningkatan kemampuan sumber daya manusia melalui kemampuannya untuk memberikan KIE terhadap masyarakat, sehingga mampu menggunakan fasilitas pelayanan kesehatan dan memberikan pendidikan salah satunya tentang cara pemberian ASI Eksklusif. ${ }^{12}$

\section{Metode}

Desain penelitian yang digunakan dalam penelitian ini adalah menggunakan desain penelitian deskriptif analitik dengan pendekatan Cross Sectional. ${ }^{13}$ Untuk mengetuhui gambaran serta variable bebas yang terdiri dari umur, paritas, pendidikan, pekerjaan, dan pendapatan keluarga dengan variable terikat. Penelitian ini dilakukan di BPM Bidan Y Kabupaten Bogor Tahun 2019 menggunakan data sekunder. Sampel penelitian ini adalah dengan mengambil total populasi yaitu seluruh ibu yang memiliki bayi 06 bulan sebanyak 95 orang.. Analisis data univariat dan bivariat dilakukan untuk mengetahui hubungan antara dua variabel yang diteliti. $^{14}$

\section{Hasil}

Tabel 1. Pemberian MP ASI Dini

\begin{tabular}{ccc}
\hline MP ASI Dini & F & \% \\
\hline Ya & 19 & 20 \\
Tidak & 76 & 80 \\
Total & 95 & 100 \\
\hline
\end{tabular}

Pada tabel 1 dapat dilihat bahwa dari seluruh responden yang berjumlah 95 orang diperoleh responden dengan katagori Pemberian MP ASI Dini tidak diberikan sebanyak 76 orang (80\%) sedangkan yang ya di berikan MP-ASI sebanyak 19 orang $(20 \%)$.

Berdasarkan tabel 2 dibawah menunjukkan hasil analisi data terhadap 95 orang responden dilihat dari usia terbanyak pada ibu usia 20-35 tahun yaitu 49 orang (51\%), dari tingkat pendidikan terbanyak pendidikan rendah 59 orang $(62 \%)$, dari paritas ibu terbanyak multi 81 orang $(85 \%)$, dari pekerjaan terbanyak ibu bekerja 51orang (53\%) dan pengetahuan kurang terbanyak $65(70 \%)$.

Berdasarkan Tabel 3 menjelaskan hasil penelitian hubungan usia dengan pemberian MPASI 0 - 6 bulan dapat diketahui dari 49 orang yang berusia $<20->35$ tahun sebanyak 
Tabel 2. Distribusi Responden Menurut Karakteristik

\begin{tabular}{ccccc}
\hline No & Variabel & Kategori & Jumlah & \% \\
\hline 1 & Usia & $<25->35$ & 49 & 51 \\
& & $20-35$ & 46 & 49 \\
2 & Pendidikan & Rendah & 59 & 62 \\
& & Tinggi & 36 & 38 \\
3 & Paritas & Primi & 14 & 15 \\
& & Multi & 81 & 85 \\
4 & Pekerjaan & Tidak & 44 & 47 \\
& & Bekerja & 51 & 53 \\
5 & Pengetahuan & Kurang & 65 & 70 \\
& & Baik & 30 & 30 \\
\hline
\end{tabular}

Tabel 3. Distribusi Pemberian MP- ASI Dini menurut Variabel Karakteristik Responden

\begin{tabular}{|c|c|c|c|c|c|c|c|c|}
\hline \multirow[t]{3}{*}{ Variabel } & \multicolumn{8}{|c|}{ MP ASI Dini Usia 0-6 Bulan } \\
\hline & \multicolumn{4}{|c|}{ Tidak } & \multicolumn{4}{|l|}{ Ya } \\
\hline & Kategori & $\mathbf{N}$ & $\%$ & $\mathbf{N}$ & $\%$ & Total & $\mathbf{P v}$ & OR \\
\hline \multirow[t]{2}{*}{ Usia } & $<25->35$ & 41 & 53,9 & 8 & $\overline{42,1}$ & 49 & 0,505 & 1,61 \\
\hline & $25-35$ & 35 & 46,1 & 11 & 57,9 & 46 & & \\
\hline \multirow[t]{2}{*}{ Pendidikan } & Rendah & 52 & 68,4 & 7 & 36,8 & 59 & 0,023 & 3,714 \\
\hline & Tinggi & 24 & 31,6 & 12 & 63,2 & 36 & & \\
\hline \multirow[t]{2}{*}{ Paritas } & Primi & 68 & 89,5 & 13 & 68,4 & 81 & 0,031 & 3,923 \\
\hline & Multi & 8 & 10,5 & 6 & 31,6 & 14 & & \\
\hline \multirow[t]{2}{*}{ Pekerjaan } & Bekerja & 35 & 46,1 & 16 & 84,2 & 51 & 0,006 & 0,16 \\
\hline & Tidak & 41 & 53,9 & 3 & 15,8 & 44 & & \\
\hline \multirow[t]{2}{*}{ Pengetahuan } & Kurang & 60 & 83 & 5 & 15 & 65 & 0 & 10.5 \\
\hline & Baik & 16 & 17 & 14 & 85 & 30 & & \\
\hline
\end{tabular}

41 orang $(53,9 \%)$ tidak memberi MP- ASI dan 8 orang memberi MP- ASI. Sedangkan dari 46 orang $(48.4 \%)$ berusia $20-35$ tahun sebanyak 35 orang $(53,9 \%)$ tidak memberi MP- ASI dan 11 orang memberi MP- ASI. Hasil uji statistik chi square, diperoleh nilai $\mathrm{p}$ value $=0,505>\alpha(0,05)$, maka dapat disimpulkan tidak adanya hubungan yang signifikan antara usia ibu dengan pemberian MP - ASI DINI, dengan nilai $\mathrm{OR}=1,610$ yang artinya ibu yang berumur $<20->35$ tahun mempunyai risiko 1,6 kali memberikan MP - ASI DINI dibandingkan ibu yang berumur 20 - 35 tahun.

Berdasarkan katagori pendidikan diketahui dari 59 orang $(62,1 \%)$ yang berpendidikan rendah dimana tidak memberikan MP- ASI sebanyak 52 orang $(68,4,8 \%)$ dan yang memberikan MP- ASI hanya 7 orang $(36,8 \%)$. Sedangkan pada 36 orang $(37,9 \%)$ yang berpendidikan tinggi didapatkan yang tidak memberi MP- ASI sebanyak 24 orang $(31,6 \%)$ dan yang memberi MP- ASI sebanyak 12 orang $(63,2 \%)$. Hasil uji statistik chi square, diperoleh nilai $\mathrm{p}$ value $=$ $0,023<\alpha(0,05)$, maka dapat disimpulkan adanya hubungan yang signifikan antara pendidikan ibu dengan pemberian MP - ASI DINI, dengan nilai $\mathrm{OR}=\mathrm{OR}=3,714$ yang artinya ibu yang yang berpendidikan rendah berpeluang 3,7 kali lebih besar tidak memberikan MP-ASI dibandingkan dengan ibu yang berpendidikan lebih tinggi.

Berdasarkan katagori paritas diketahui dari 14 orang $(14,7 \%)$ primipara yang tidak memberi MP- ASI sebanyak 8 orang $(10,5 \%)$ dan yang memberi MP- ASI sebanyak 6 orang $(31,6 \%)$. sedangkan dari 81 orang $(85,3 \%)$ multipara yang tidak memberi MP- ASI sebanyak 68 orang $(89,5 \%)$ dan yang memberi MP- ASI sebanyak 13 orang $(68,4 \%)$. Hasil uji statistik chi square, diperoleh nilai $\mathrm{p}$ value $=0,031<\alpha(0,05)$, maka dapat disimpulkan adanya hubungan yang 
signifikan antara paritas dengan pemberian MP - ASI DINI, dengan nilai $\mathrm{OR}=\mathrm{OR}=$ 3,923 yang artinya ibu dengan multi paritas berpeluang 3,9 kali lebih besar tidak memberikan MP-ASI diba ndingkan dengan ibu yang primi paritas.

Berdasarkan katagori pekerjaan diketahui dari 51 orang $(53,7 \%)$ yang bekerja, 35 orang $(46,1 \%)$ diantaranya tidak memberikan MP- ASI dan yang memberi MP- ASI hanya 16 orang $(84,2 \%)$. Sedangkan dari 44 orang $(46,3 \%)$ yang tidak bekerja yang tidak memberi MP- ASI yaitu sebanyak 41 orang $(53,9 \%)$ dan hanya 3 orang $(15,8 \%)$ yang memberikan MP- ASI. Hasil uji statistik chi square, diperoleh nilai $\mathrm{p}$ value $=0,006<\alpha(0,05)$, maka dapat disimpulkan adanya hubungan yang signifikan antara pekerjaan dengan pemberian MP - ASI DINI, dengan nilai $\mathrm{OR}=\mathrm{OR}=0.16$ yang artinya ibu yang tidak bekerja berpeluang 0.16 kali lebih besar tidak memberikan MP-ASI dibandingkan dengan ibu yang bekerja.

Bengetahuan diketahui dari 65 orang (70\%) yang Pengetahuan kurang, 60 orang (83\%) diantaranya tidak memberikan MPASI dan yang memberi MP- ASI hanya 5 orang (15\%). Sedangkan dari 30 orang (30\%) yang pengetahuan baik tidak memberi MP- ASI yaitu sebanyak 16 orang (17\%) dan 14 orang $(85 \%)$ yang memberikan MPASI. Hasil uji statistik chi square, diperoleh nilai $\mathrm{p}$ value $=0,000<\alpha(0,05)$, maka dapat disimpulkan adanya hubungan yang signifikan antara pengetahuan dengan pemberian MP - ASI DINI, dengan nilai $\mathrm{OR}=10,5$ yang artinya ibu yang pengetahuan kurang berpeluang 10.5 kali lebih besar tidak memberikan MP-ASI dibandingkan dengan ibu yang berpengetahuan baik.

\section{Pembahasan}

\section{Usia Ibu dengan Pemberian MP- ASI DINI}

Hasil penelitian hubungan usia dengan pemberian MP- ASI 0 - 6 bulan dapat diketahui dari 49 orang yang berusia <20$>35$ tahun sebanyak 41 orang $(53,9 \%)$ tidak memberi MP- ASI dan 8 orang memberi MP- ASI. Sedangkan dari 46 orang (48.4\%) berusia 20-35 tahun sebanyak 35 orang (53,9 $\%)$ tidak memberi MP- ASI dan 11 orang memberi MP- ASI. Hasil uji statistik chi square, diperoleh nilai $\mathrm{p}$ value $=0,505>\alpha(0,05)$, maka dapat disimpulkan tidak adanya hubungan yang signifikan antara usia ibu dengan pemberian MP - ASI DINI, dengan nilai OR= 1,610 yang artinya ibu yang berumur $<20->35$ tahun mempunyai risiko 1,6 kali memberikan MP - ASI DINI dibandingkan ibu yang berumur 20 - 35 tahun.

Hal ini tidak sesuai dengan teori Diana (2009) yang menyatakan ibu yang lebih muda cenderung untuk menyusui bayinya lebih dini dan semakin bertambah umur ibu semakin tinggi kecenderungan ibu untuk memberikan Makanan Pendamping ASI. ${ }^{9}$ Telah banyak teori yang memperlihatkan bahwa ibu - ibu yang lebih tua usianya akan lebih sedikit memberikan ASI. ${ }^{15}$ Pembuktian ini dikaitkan dari suatu analisis mengenai produksi susu yang dihasilkan oleh ibu pada tujuh hari setelah postpartum. Ibu yang berusia antara <20->35 tahun akan mempunyai Asi lebih sedikit dibandingkan dengan ibu- ibu yang berusia $20-35$ tahun. ${ }^{16}$

Hasil penelitian ini tidak sejalan dengan teori yang mengemukakan bahwa usia ideal untuk hamil dan melahirkan atau mempunyai anak, harus mempersiapkan 3 hal yaitu kesiapan fisik, kesiapan mental/psikologis dan kesiapan sosial atau ekonomi, secara umum seorang perempuan dikatakan siap secara fisik sekitar usia 20 tahun bila dijadikan pedoman kesiapan fisik. $^{19}$ Dengan kesiapan fisik tersebut, maka proses kehamilan dan persalinan juga dapat berjalan dengan optimal. Kondisi organ tubuh wanita dalam menjalankan kehamilan dan persalinan akan sangat baik pada usia $20-35$ tahun. ${ }^{20}$

Selain itu, Notoatmodjo (2016) juga mengemukakan bahwa umur merupakan faktor pencetus bagi timbulnya perilaku pada diri seseorang. Ibu yang berumur lebih dewasa memiliki pemahaman dan pengalaman lebih baik dibandingkan dengan ibu yang berumur kurang dewasa, hal tersebut akan mempengaruhi perilakunya terhadap pemberian MP -ASI Dini pada bayinya. ${ }^{14}$

\section{Pendidikan dengan Pemberian MP ASI DINI}

Hasil berdasarkan katagori pendidikan diketahui dari 59 orang $(62,1 \%)$ yang berpendidikan rendah dimana tidak

memberikan MP- ASI sebanyak 52 orang $(68,4,8 \%)$ dan yang memberikan MP- ASI hanya 7 orang $(36,8 \%)$. Sedangkan pada 36 orang 
$(37,9 \%)$ yang berpendidikan tinggi didapatkan yang tidak memberi MP- ASI sebanyak 24 orang $(31,6 \%)$ dan yang memberi MP- ASI sebanyak 12 orang $(63,2 \%)$. Hasil uji statistik chi square, diperoleh nilai $\mathrm{p}$ value $=0,023<\alpha(0,05)$, maka dapat disimpulkan adanya hubungan yang signifikan antara pendidikan ibu dengan pemberian MP - ASI DINI, dengan nilai $\mathrm{OR}=\mathrm{OR}=3,714$ yang artinya ibu yang yang berpendidikan rendah berpeluang 3,7 kali lebih besar tidak memberikan MP-ASI dibandingkan dengan ibu yang berpendidikan lebih tinggi.

Hal ini sesuai dengan teori menurut Notoatmodjo (2016) yaitu Pendidikan yang semakin tinggi akan cepat tanggap terhadap masalah-masalah kesehatan dan mudah mengikuti petunjuk dari petugas kesehatan. ${ }^{14}$ Selain itu ibu yang terpelajar memiliki fasilitas yang lebih baik dan posisi yang lebih memungkinkan mereka untuk menyusui dibandingkan dengan ibu yang kurang terpelajar. Penelitian ini sesuai dengan teori diatas dan juga penenlitian Ruliana (2015) yang memperoleh hubungan pendidikan dengan pekerjaan adalah bermakna. ${ }^{17}$

Pendidikan pada hakekatnya bertujuan mengubah tingkah laku sasaran pendidikan. Tingkah laku baru (hasil perubahan) itu dirumuskan dalam suatu tujuan pendidikan (educational objective), sehingga tujuan pendidikan pada dasarnya adalah suatu deskripsi dari pengetahuan, sikap, tindakan, penampilan dan sebagainya yang diharapkan akan dimiliki sasaran pendidikan pada periode tertentu. ${ }^{18}$

Ibu yang berpendidikan tinggi, otomatis akan memiliki wawasan lebih baik dibandingkan dengan ibu yang pendidikannya rendah, sehingga dengan wawasannya yang baik, akan berkontribusi terhadap perilakunya untuk memberikan pemdamping MP ASI yang tepat terhadap bayinya. $^{19}$

\section{Paritas dengan pemberian MP-ASI DINI}

Berdasarkan katagori paritas diketahui dari 14 orang $(14,7 \%)$ primipara yang tidak memberi MP- ASI sebanyak 8 orang $(10,5 \%)$ dan yang memberi MP- ASI sebanyak 6 orang $(31,6 \%)$. sedangkan dari 81 orang $(85,3 \%)$ multipara yang tidak memberi MP- ASI sebanyak 68 orang $(89,5 \%)$ dan yang memberi MP- ASI sebanyak 13 orang $(68,4 \%)$. Hasil uji statistik chi square, diperoleh nilai $\mathrm{p}$ value $=0,031<\alpha(0,05)$, maka dapat disimpulkan adanya hubungan yang signifikan antara paritas dengan pemberian MP - ASI DINI, dengan nilai $\mathrm{OR}=\mathrm{OR}=3,923$ yang artinya ibu dengan multi paritas berpeluang 3,9 kali lebih besar tidak memberikan MP-ASI diba ndingkan dengan ibu yang primi paritas.

Hasil penelitian ini sesuai dengan yang ditemukan Ruliana (2015) yang menjelaskan pada ibu-ibu yang baru pertama kali mempunyai anak atau primipara lebih banyak memiliki masalah dalam menyusui, berbeda halnya pada ibu-ibu multipara yang sudah mengalami masa menyusui sebelumnya. Megawati (2010) juga menyatakan bahwa terdapat hubungan yang bermakna antara paritas dengan MP-ASI 0-6 bulan. ${ }^{15,24}$

Hasil penelitian ini sesuai dengan teori yang di kemukakan oleh Wiknjosastro (2007), mengemukakan paritas >3 cenderung memiliki waktu lebih untuk mempelajari sesuatu sehingga memiliki pengetahuan yang lebih tinggi. ${ }^{21}$ Safitrii (2017) juga mengemukakan ibu yang memiliki paritas $>4$ akan memiliki pengetahuan yang lebih baik mengenai pengetahuan ASI Eksklusif. ${ }^{25}$ Menurut teori World Health Organization (WHO) yang dikutip oleh Notoatmodjo (2016), salah satu bentuk objek kesehatan dapat dijabarkan oleh pengetahuan yang diperoleh dari pengalaman sendiri. ${ }^{18}$ Dari teori tersebut peneliti berpendapat semakin banyak pengalaman sendiri dalam hal ini paritas yang di maksud maka risiko yang akan terjadipun akan semakin tinggi terhadap pemberian makanan pendamping ASI secara dini. Sebaliknya bagi mereka yang berparitas rendah maka risiko pemberian MPASI pun akan rendah. ${ }^{27}$ Hasil uji hubungan yang dilakukan peneliti ini juga sejalan dengan penelitian yang dilakukan oleh Ginting (2009) mengenai pengaruh karakteristik, faktor internal dan eksternal ibu terhadap pemberian MP-ASI dini pada bayi usia. ${ }^{20}$

\section{Pekerjaan dengan Pemberian MP ASI DINI}

Berdasarkan katagori pekerjaan diketahui dari 51 orang $(53,7 \%)$ yang bekerja, 35 orang $(46,1 \%)$ diantaranya tidak memberikan MP- ASI dan yang memberi MP- ASI hanya 16 orang $(84,2 \%)$. Sedangkan dari 44 orang $(46,3 \%)$ yang tidak bekerja yang tidak memberi MP- ASI yaitu sebanyak 41 orang $(53,9 \%)$ dan hanya 3 orang 
$(15,8 \%)$ yang memberikan MP- ASI. Hasil uji statistik chi square, diperoleh nilai $\mathrm{p}$ value $=0,006<\alpha(0,05)$, maka dapat disimpulkan adanya hubungan yang signifikan antara pekerjaan dengan pemberian MP - ASI DINI, dengan nilai $\mathrm{OR}=\mathrm{OR}=0.16$ yang artinya ibu yang tidak bekerja berpeluang 0.16 kali lebih besar tidak memberikan MP-ASI dibandingkan dengan ibu yang bekerja.

Hal ini sesuai dengan teori yaitu Menurut Dhiana, (2006) bahwa terdapat hubungan yang bermakna antara pekerjaan ibu dengan pemberian makanan pralaktal. Dan juga ditemukan bahwa, ibu yang bekerja lebih banyak yang menyusui bayinya lebih dini, memberikan kolostrum dan tidak memberikan makanan pralaktal. Berdasarkan hasil penelitian Endang (2009), bahwa ada hubungan antara status pekerjaan ibu dengan pemberian ASI ekslusif dan pralaktal. $^{26}$

\section{Pengetahuan dengan Pemberian MP ASI DINI}

Bengetahuan diketahui dari 65 orang (70\%) yang Pengetahuan kurang, 60 orang (83\%) diantaranya tidak memberikan MPASI dan yang memberi MP- ASI hanya 5 orang (15\%). Sedangkan dari 30 orang (30\%) ssyang pengetahuan baik tidak memberi MP- ASI yaitu sebanyak 16 orang $(17 \%)$ dan 14 orang (85\%) yang memberikan MP- ASI. Hasil uji statistik chi square, diperoleh nilai $\mathrm{p}$ value $=0,000<\alpha$ $(0,05)$, maka dapat disimpulkan adanya hubungan yang signifikan antara pengetahuan dengan pemberian MP - ASI DINI, dengan nilai $\mathrm{OR}=10,5$ yang artinya ibu yang pengetahuan kurang berpeluang 10.5 kali lebih besar tidak memberikan MPASI dibandingkan dengan ibu yang berpengetahuan baik.

Hal ini sesuai dengan teori Notoatmodjo (2016) dengan tahu memahami pengetahuan yang baik tahu dan dapat menyebutkan pengertian dan manfaat ASI dan makanan pendamping ASI. ${ }^{14,}{ }^{28}$ Selain itu ibu yang tingkat pengetahuan nya baik memiliki pengetahuan yang lebih dalam memberikan ASI Ekslusif dan lebih memungkinkan mereka untuk full pemberian hanya ASI saja sampai usia bayi mereka 6 bulan dibandingkan dengan ibu yang pengetahuan nya kurang (Intan,
2013) ${ }^{29}$ Penelitian ini sesuai dengan teori diatas dan juga penenelitian Firdayanti (2011) yang memperoleh hubungan pengetahuan dengan pemberian MP ASI Dini adalah bermakna Sehubungan dengan faktor pengetahuan di atas, ASI yang tidak cukup merupakan alasan paling sering bagi ibu yang ingin cepat memberikan bayi mereka susu sapi atau bubur dari tepung biji-bijian. ${ }^{30}$

\section{Kesimpulan}

Terdapat faktor yang mempengaruhi antara pemberian MP-ASI Dini serta memiliki pengaruh yang signifikan yakni hubungan dengan pendidikan ibu, paritas, pekerjaan dan pengetahuan ibu.

\section{Saran}

Diharapkan semua tenaga kesehatan khususnya bidan, perlu meningkatkan penyuluhan mengenai pemberian makanan pendamping ASI kepada masyarakat sehingga pemberian MP-ASI dini dapat diminimumkan. Selain itu tenaga kesehatan juga harus bekerjasama dengan kader, tokoh masyarakat sehingga masyarakat semakin tahu dan sadar pemberian makanan pendamping ASI sebelum waktunya akan berakibat buruk.

\section{Daftar Pustaka}

1. Depkes RI.Makanan Pendamping ASI (MP - ASI). Jakarta ; 2017.

2. Panduan Inisiasi Menyusui Dini. Dr.Utami Roeli. Jakarta : Pustaka Bunda; 2012

3. Endang. Faktor-faktor yang Berhubungan dengan Praktek Pemberian Makanan Pendamping ASI (MP-ASI) Dini Pada Bayi 0-6 bulan, 2012 [Skripsi]. Fakultas Kesehatan Masyarakat Universitas Indonesia: Depok; (Diakses tangal 02 Februari 2019).

4. Febriana N. Faktor-faktor yang berhubungan dengan Pemberian ASI Secara Ekslusif oleh Ibu Usia 15 - 35 Tahun Pada Bayinya yang Berusia 0 - 6 Bulan.2017. Fakultas Kesehatan Masyarakat Universitas Indonesia: Depok ; Diunduh tanggal 05 Maret 2019.

5. Dhiana I. Pola Pemberian ASI dan Kematian Bayi di Kec. Gabus Wetan \& Sliyeg Kab. Indramayu, Jawa Barat Tahun 2005-2006, Skripsi FKM UI, Depok.2016 (Diakses tanggal 12 September 2018).

6. WHO. Manajemen Laktasi, Buku Panduan Bagi Bidan dan Petugas Kesehatan di Puskesmas. Jakarta :2017.

7. Depkes RI. Pedoman Teknis Tempat kerja Sayang Bayi. Jakarta: 2015.

8. Latief D, dkk ; Program ASI Eksklusif dan Makanan Pendamping ASI (MP - ASI). Dalam 
Kumpulan Makalah Diskusi Pakar Bidang Gizi Tentang ASI, MP-ASI, Antropometri dan BBLR. Cipanas 19-21 Januari 2011. (Diunduh tanggal 13 Desember 2018).

9. Fikawati, S., dan A. Syafiq. Hubungan antara menyusui segera (immediate breastfeeding) dan pemberian ASI ekslusif sampai dengan empat bulan. Jurnal Kedokteran Trisakti. FK Trisakti.2012 (Diunduh tanggal 24 Januari 2019).

10. Garza C. Infant Feeding Recomendation. American Journal Clinical Nutrition Vol 67, USA: 2017.

11. Irianto J.Pola Pemberian ASI dan Makanan/Minuman Tambahan Pada Bayi Baru Lahir Serta Hubungannya dengan Tempat bersalin dan Penolong Persalinan. [Skripsi]. Fakultas Kesehatan Masyarakat Universitas Indonesia Depok. 2013 (Diunduh tanggal 20 Februari 2019).

12. Ramaiah S. Manfaat ASI dan Menyusui Panduan Praktis Bagi Ibu Setelah Melahirkan. Jakarta: PT Bhuana Ilmu Populer; 2017.

13. Hidayat. Metode Penelitian Kebidanan Dan Tehnik Analisis Data, Cetakkan KeTiga, Jakarta: Salemba Medika; 2017.

14. Notoatmojo S. Metode Penelitian masyarakat. Jakarta: PT Rineka Cipta; 2016.

15. Suriana, Studi Pola Pemberian ASI \& Permasalahannya di Pedesaan dan Perkotaan di Dati II Bogor dan Cirebon. [Skripsi].GMSK. IPB Bogor; 2012

16. Sutayani. Hubungan Pemberian Makanan Prelakteal dengan Proses Menyusui di Wilayah Kerja Puskesmas Rowotengah Kecamatan Sumber Baru Jember. 2012. [Skripsi]. Universitas Jember (Diunduh tanggal 10 Oktober 2018).

17. Suriadi R. Usaha Peningkatan Penggunaan ASI, Simposium Permasalahan Gizi pada Balita. Jakarta: 2015.

18. A. Wawan dan Dewi M. Teori \& Pengukuran Pengetahuan Sikap dan Perilaku Manusia. Yogyakarta: Nuha Medik; 2010.

19. Hegar B, dkk. Bedah ASI. Jakarta: Balai Penerbit FKUI; 2014.

20. Ginting D. Pengaruh Karakteristik, Faktor Internal dan Eksternal Ibu terhadap Pemberian MP-ASI Dini Pada Bayi Usia 6 bulan. Jakarta 2012. (Diunduh tanggal 12 September 2018)

21. Wiknjosastro H. Ilmu Kebidanan. Edisi Ketiga, Cetakan Kedelapan. Yayasan Bina Pustaka Sarwono Prawirohardjo; 2012.

22. Green L. Health Education Planning.A Diagnostic Approch. The John Hopkins University Mayfield Publishing Co, 2000.

23. Kodrat L. Dahsyatnya ASI dan Laktasi. Yogyakarta: Media Baca;2013.
24. Maryunani A. Asuhan Pada Ibu dalam Masa Nifas (Postpartum). Jakarta: CV. Trans Info Media; 2015.

25. Meliono I dkk.. MPKT Modul 1. Jakarta: Lembaga Penerbitan FKUI; 2017.

26. Notoatmojo S. Metode Penelitian Kesehatan. Jakarta: PT Rineka Cipta; 2015.

27. Wisnuwardhani SD. Praktek Menyusui Yang Benar. Jakarta : Pustaka; 2018.

28. http://digilib.litang.depkes.go.id/- Badan Litbang Kesehatan-GDL 4.0 (Diunduh pada tanggal 30 Oktober 2018)

29. Linkages academ foreducational development washingtong DC 2015 http://www.linkagesproject.org (Diunduh pada tanggal 23 Februari 2019)

30. http://www.mediafire.com (Diunduh pada tanggal 14 Januari 2019) 